\title{
日本語の学習を継続しない理由についての一考察 \\ 一台湾の非日本語学科の大学生の場合一 \\ Survey of why non-Japanese major students stop learning Japanese
}

\section{王敏東 \\ 台湾科技大学 応用外国語学科}

\section{要旨}

本稿は大学生が日本語を継続して学習しない理由、及びそれらの理由がなくなれば はたして彼らは日本語の学習を継続するか、について探るものである。具体的には日本語を 1 学期しか履修していない 2 校の大学生 88 人を対象にアンケート調査を行い、その結果を 分析した。アンケートは日本語を 1 学期間履修した後、2 度と日本語を履修しなかった 理由（27 項目）と、それらの理由がなくなれば履修するか（27 項目）という2つの部分 から構成されている。「学生が日本語を継続して学習しない理由（27 項目）」と「それらの 理由がなくなった場合に学生が継続して学習する意思（27 項目）」との間に相関関係は 検出されなかった。なお、学生が日本語を継続して学習しない27 の理由のうち、それらの

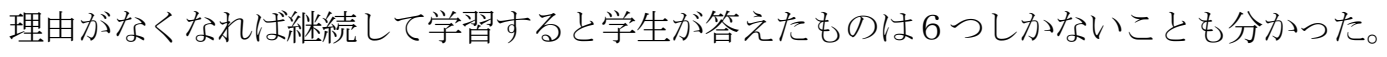
調査結果により、「学生が卒業する前に」、他の勉学やアルバイドが忙しすぎない前提で」、 「別の授業と時間が重ならないよう」、「よい時間帯に」、「より上級の日本語のクラスを 開講すること」を配慮すれば、学生が続けて日本語を履修するようになる可能性が大きい、 と分かった。

キーワード :

日本語継続学習支援、質問の仕方、相関関係 


\section{日本語の学習を継続しない理由についての一考察 \\ 一台湾の非日本語学科の大学生の場合一}

\section{王敏東 \\ 台湾科技大学 応用外国語学科}

\section{1. はじめに}

日本語は、英語を除くと台湾で最も多くの人が学習する外国語である。しかし、近年、 学習人口が以前ほどの増加ぶりを見せなくなった1。また、日本語の学習を始めた後、何ら かの理由で上級のクラスに行かない人もかなり多い2。学生の外国語学習の継続が困難 になる理由を探るものとして、いくつかの論考がある。そのような論考には、日本語を 履修した学生を対象に、日本語学習を続けない理由について調査したものが多い。学生が 日本語を継続して学習しない理由を明らかにすることはまず必要であるが、それらの 理由がなくなれば彼らが本当に教室に戻ってくるか、という点についての考察は管見の 限り見当たらない。その点について究明するため、本研究では、学生が日本語を継続して 学習しない理由は何か、及びそれらの理由がなくなれば学習をする気持ちがあるのか、 という点について調査した。

\section{2. 先行研究}

周（2009）は日本語教室をやめた中国人学習者 10 名にインタビューし、日本語教室を

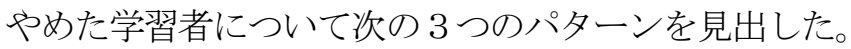

（1）交流が目的で日本語教室に通い、やむをえない事情でやめたパターン。

（2）日本語の勉強が目的で日本語教室に通い、教室になんらかの不満をもったために やめたパターン。

（3）日本語の勉強が目的で日本語教室に通い、やむをえない事情でやめたパターン。 岩本 (2010) はアメリカ在住の日本語学習者 10 名と日本在住の英語学習者 4 名を対象に、 外国語を継続して学習した理由について質的な調査 (ヒストリー)をした。その結果から、 学習者が外国語を継続して学習するには「学習支援者の存在」「自己効率感」「成功体験」、

「自律学習」が大事だと指摘している。

1 国際交流基金（2016）。王・謝は台湾教育部が公表した、台湾における 2010 年以来（英語以外の） 各外国語の履修者数（高校生および大学生）の変化を、外国語ごとに整理・分析し、日本語を履修する 学生の人数は依然として多数を占めているが、その比率は年々下降していることを明らかにした

（王・謝（2017））。近年学習できる外国語の種類が増える一方、いろいろな外国の芸能関係などの 情報も前より簡単に入手できるようになったことが原因であり、日本の経済力が以前ほどでないことや、 日本に対する知識が増え、日本に対する好奇心が弱くなったということも影響していると述べている

(王・謝 $(2017: 15)$ )。

2 葉 $(2013: 1 、 3 \sim 6)$ 
近藤・村中（2010）はパリ日本文化会館の日本文化関連事業の来場者 83 名を対象に質問 紙調査をしたものである。その結果をもとに、日本語を普及する上でポップカルチャーに 関心が強い人を日本語学習者としてターゲットにすることは効果的である、という仮説が 提示されているが、学習開始後の継続学習支援の方法については依然として未解決の課題 を残している。

吳（2011）は日本語を第 2 外国語として学習した銘傳大学の学生を対象としたインタ ビュー調査で、日本語学習を中断した理由として、以前の研究では言及されなかった 「アルバイト」が含まれることを指摘している。

葉（2013）は日本語を履修した非日本語学科の学生 187 名を対象にアンケート調査を した。SPSSにより統計的に分析した結果、学生が続けて日本語を履修しようとしない理由 について、個人的な理由、授業に由来した理由、やむを得ない理由、教師に由来した理由、 という4つの因子を抽出した。

洪 (2016: 199) は日本語の学習をやめた非日本語学科の学生 107 人を対象とした調査で、 学科の専門科目の勉強を優先すること、アルバイトに忙しいこと、日本語がある程度上達 するまで予想より多くの学習時間が必要であること、上級クラスが少ないことなどが学生 の日本語の継続学習を妨げる理由であることをまとめた。

このように、いくつかの論考の中で、学生が日本語学習を継続しない理由が学習動機 などとあわせて検討されており、学習を継続しない理由がかなり明確にされているが、 それらの理由がなくなったら学生が日本語の学習を継続するか、ということは探究されて いない。

以上のことに基づき、本研究では学生が日本語学習を継続しない理由と、それらの 理由がなくなれば学生が日本語学習を継続するか、という 2 方向から調査を行い、効果の ある日本語継続学習支援の方法を探りたい。

\section{3. 調查方法}

本研究は日本語を 1 学期しか履修していない大学生を対象にアンケート調査をする。具 体的には 2014 年 9 月〜 2017 年 6 月の 3 年間で、第二外国語としての日本語を 1 学期しか履 修していない大学生を調査対象とした。

${ }^{3}$ 洪 (2016：199) はさらに、試験に由来する挫折も1つの理由ではないかと推測している。 


\section{日本語の学習を継続しない理由についての一考察}

一台湾の非日本語学科の大学生の場合一

\section{1 アンケートの作成}

アンケートの内容は、前掲の「2 . 先行研究」に取り上げた論文を参考にした他、 2017 年 7 月に、日本語を 1 学期しか履修していない大学生 8 人にインタビューして得た 情報に基づいて作成した。

8 人が日本語を続けて履修しなかった理由は次の通りである。

「続けて日本語を履修したかったが、専門科目が多くて、なかなか専攻でない日本 語を取る余裕はなかった。」（4人）、

「同じ時間に別の必修科目を取らなければならなかったから」（3人）、

「最初は友達と一緒に日本語を取ったなど、不本意な理由で日本語の勉強を始めた。 自分が不真面目だったこともあり、途中から日本語が難しくなるとだんだん皆に 追いつけなくなったため、続けて勉強するのをやめた。（2人)、

「最初はなるべく早いうちに卒業できる最低単位数を満たすため、日本語を取った。 希望通り単位が取れたので、続けて履修しなかった。来年日本へ遊びに行くので、 また日本語の勉強を再開する。」（1 人 $\left.{ }^{4}\right)$

このアンケートで、学生が日本語を 1 学期間履修した後、2 度と日本語を履修しなかった 理由を 27 個設定した。これらの理由について、それぞれ「非常に当てはまる」（5）から 「ぜんぜん当てはまらない」（1）まで、5段階で回答するアンケートを作成した。一方、 この 27 の理由がなくなれば学生が日本語の学習を継続するか、についても探るため、それ らの理由がなくなった場合に継続して学習する意思を問う 27 項目もアンケートに入れた。

上記の手順で作成したアンケートを用い、日本語を 1 学期しか履修していない大学生 10 人を対象に 2017 年 7 月末にプリテストをした。文字、表現を若干修正して、2017 年 7 月末〜 9 月中旬に正式な調査を行った 5 。

\section{2 調查対象}

繰り返しになるが、本研究は 2014 年 9 月〜2017 年 6 月という 3 年間で、日本語を 1 学期 しか履修していない大学生を調査対象とした。大学在学期間中の他の時期（2014 年 9 月 以前もしくは 2017 年 9 月以降) にも日本語を履修している学生は対象から除外する。調査 は日本語が第 2 外国語の選択科目としてしか開講されていない 2 大学 6 で実施した。

\footnotetext{
${ }^{4} 1$ 人で複数の理由に触れた人がいるので、括弧内の人数の合計は総人数 8 人を超えた。

5 正式に調査を行ったアンケートは付録の通りである。

62 大学とも台北市にある国立大学である。
} 
アンケートはE-mail、FB、友人経由、の3 通りの方法で配布した。回収したもののうち 有効回答数は 88 部だった。本研究の分析の対象となった学生の詳細は表 1 のようになって いる。

表 1 調査対象となる学生の詳細

\begin{tabular}{|c|c|c|c|}
\hline & & & 㑔人 \\
\hline \multirow{2}{*}{ 性別 } & 男 & \multicolumn{2}{|c|}{55} \\
\hline & 女 & \multicolumn{2}{|c|}{33} \\
\hline \multirow{6}{*}{ 学部 } & 電気工学 & 14 & \multirow{3}{*}{$\begin{array}{c}\text { (理系) } \\
58\end{array}$} \\
\hline & 工学 & 13 & \\
\hline & 医学 & 31 & \\
\hline & 管理 & 18 & \multirow{3}{*}{$\begin{array}{c}\text { （文系） } \\
30\end{array}$} \\
\hline & デザイン & 8 & \\
\hline & 人文社会 & 4 & \\
\hline 計 & & \multicolumn{2}{|c|}{88} \\
\hline
\end{tabular}

*数字は人数

\section{4. 調査結果の分析}

アンケートの信頼性は表 2 に示すように、Cronbach's Alpha が. 866 と.970 となって おり、良好であることが分かる。

表 2 アンケートの信頼性 (Reliability Statistics)

\begin{tabular}{|r|r|r|}
\hline & $\begin{array}{c}\text { Cronbach's } \\
\text { Alpha }\end{array}$ & $\begin{array}{c}\text { 項目数 } \\
\text { (N of Items) }\end{array}$ \\
\hline 日本語を続けて履修しない理由 $(1 \sim 27$ 項目) & .866 & 27 \\
\hline 前記の理由がない場合日本語を続けて履修する意思 $(28 〜 54$ 項目) & .970 & 27 \\
\hline
\end{tabular}

\section{1 学生が日本語を続けて履修しない理由と、その理由がない場合に続けて履修する 意思の叙述統計}

学生が日本語を続けて履修しない理由における叙述統計（表 $3 \mathrm{~A}$ の欄）を、それらの理由 がない場合に続けて日本語を履修する意思の叙述統計（表 3 B の欄）と照らし合わせて みれば、差があることが分かる（表 3 右の欄）。

項目「10/37 (-10)」のペアを例にすれば、日本語の学習を継続しないのは「将来日本語 をあまり使うことはないと思うから。」という理由が 1.98 という低い度合いである一方、 「将来日本語を使う機会があると思われるなら、日本語を続けて履修する。」意思は 4.07 という高い度合いを示しており、両者の間には差がある。つまり、日本語を続けて履修し ない理由として「将来日本語をあまり使うことはないと思うから。」と述べている学生の 割合はそう多くないが、「将来日本語を使う機会があると思われるなら、日本語を続けて 履修する。」意思を示した学生の割合は多いわけである。 
日本語の学習を継続しない理由についての一考察

一台湾の非日本語学科の大学生の場合一

表3学生が日本語を続けて履修しない理由と、その理由がない場合に 続けて履修する意思の記述統計

\begin{tabular}{|c|c|c|c|c|c|}
\hline \multicolumn{2}{|c|}{$\begin{array}{c}\text { 日本語を続けて履修しない } \\
\text { 理由（A） }\end{array}$} & \multicolumn{2}{|c|}{$\begin{array}{c}\text { 左記の理由がない場合続けて } \\
\text { 日本語を履修する（B） }\end{array}$} & \multicolumn{2}{|c|}{$\begin{array}{c}\text { AとBにおける } \\
\text { 平均值の差 }\end{array}$} \\
\hline 項目 & 平均值 & 項目 & 平均值 & $A-B$ & 順位 \\
\hline 1 & 1.78 & $28(-1)$ & 3. 59 & -1.81 & 10 \\
\hline 2 & 3. 49 & $29(-2)$ & 3.72 & -0.23 & 27 \\
\hline 3 & 2. 69 & $30(-3)$ & 3. 60 & -0.91 & 22 \\
\hline 4 & 3.45 & $31(-4)$ & 4. 01 & -0.56 & 26 \\
\hline 5 & 2.55 & $32(-5)$ & 3.64 & -1.09 & 21 \\
\hline 6 & 1.95 & $33(-6)$ & 3. 85 & -1.9 & 7 \\
\hline 7 & 2.80 & $34(-7)$ & 3.68 & -0.88 & 23 \\
\hline 8 & 2.70 & $35(-8)$ & 3. 49 & -0.79 & 24 \\
\hline 9 & 2.20 & $36(-9)$ & 3. 31 & -1.11 & 20 \\
\hline 10 & 1.89 & $37(-10)$ & 4. 07 & -2.18 & 3 \\
\hline 11 & 1.44 & $38(-11)$ & 3. 89 & -2.45 & 1 \\
\hline 12 & 1.65 & $39(-12)$ & 4. 06 & -2.41 & 2 \\
\hline 13 & 2.73 & $40(-13)$ & 3. 88 & -1.15 & 18 \\
\hline 14 & 2.22 & $41(-14)$ & 3. 81 & -1.59 & 12 \\
\hline 15 & 2.38 & $42(-15)$ & 3.95 & -1.57 & 14 \\
\hline 16 & 2. 05 & $43(-16)$ & 3.94 & -1.89 & 8 \\
\hline 17 & 2.07 & $44(-17)$ & 3.95 & -1.88 & 9 \\
\hline 18 & 2. 20 & $45(-18)$ & 3.78 & -1.58 & 13 \\
\hline 19 & 2. 26 & $46(-19)$ & 3.99 & -1.73 & 11 \\
\hline 20 & 2. 41 & $47(-20)$ & 3. 80 & -1.39 & 17 \\
\hline 21 & 2.27 & $48(-21)$ & 3.74 & -1.47 & 15 \\
\hline 22 & 1.81 & $49(-22)$ & 3.73 & -1.92 & 6 \\
\hline 23 & 1.74 & $50(-23)$ & 3.88 & -2.14 & 4 \\
\hline 24 & 1.50 & $51(-24)$ & 3.52 & -2.02 & 5 \\
\hline 25 & 3. 00 & $52(-25)$ & 3.67 & -0.67 & 25 \\
\hline 26 & 2.56 & $53(-26)$ & 3. 69 & -1.13 & 19 \\
\hline 27 & 2. 13 & $54(-27)$ & 3.58 & -1.45 & 16 \\
\hline 平均 & (項目 1～27) 2.29 & & (項目 28〜54) 3.77 & & \\
\hline
\end{tabular}


履修しない理由（項目）の平均值が、その理由がない場合に履修する意思の平均値より 大きいものは 1 ペアもなく、その差が大きい順に「11/38 (-11)」、「12/39 (-12)」、 $\lceil 10 / 37(-10) 」 、 「 23 / 50(-23) 」 、 「 24 / 51(-24) 」 （$ 差の大きい順に並べた場合の上位 5 位、 平均值の差が 2 以上）となっている。

それに対して、「2/29(-2)」、「4/31 (-4)」、「25/52(-25)」、「8/35(-8)」、「7/34 (-7)」の ようなペアでは、両者の間にはあまり差がない（差の大きい順に並べた場合の下位 5 位、 差が 0.9 以内)。

\section{2 学生が日本語を続けて履修しない理由と、その理由がない場合に日本語を続けて 履修する意思の相関関係}

学生が日本語を続けて履修しない理由（1２7 項目）と、その理由がない場合に日本語を 続けて履修する意思（28～54 項目）の相関関係が検出されなかった。

また、ペアとなった 2 項目間の相関関係について、互いに有意差が認められないのは $\lceil 6 / 33(-6)\rfloor 、\lceil 7 / 34(-7)\rfloor 、\lceil 8 / 35(-8)\lrcorner 、\lceil 9 / 36(-9)\rfloor 、\lceil 10 / 37(-10)\rfloor 、\lceil 11 / 38(-11) 」 、$ $\lceil 12 / 39(-12)\rfloor 、 13 / 40(-13)\rfloor 、\lceil 14 / 41(-14)\rfloor 、\lceil 15 / 42(-15)\rfloor 、\lceil 16 / 43(-16)\rfloor 、 17 / 44(-17)\rfloor 、$ $\lceil 18 / 45(-18)\rfloor\lceil 19 / 46(-19)\rfloor 、 20 / 47(-20)\rfloor 、\lceil 21 / 48(-21)\rfloor 、\lceil 22 / 49(-22)\rfloor 、 23 / 50(-50) 」 、$ $\lceil 24 / 51(-24) 」 、 25 / 52(-25) 」 、 「 26 / 53(-26) 」 と い う 21$ ペアである。つまり、日本語が 難しいと感じるかどうか、教師の教え方が自分に合っているかどうか、理想的な日本語の 成績がとれそうかどうか、英語に自信が持てるようになったかどうか、など、項目 33〜 項目 53 については、それらの理由がなくなったとしても学生が積極的に日本語の履修を 続けるとは限らないということである。これは非日本語学科の日本語教師が、学生に続けて 教室に来てもらうことの難しさを示唆している。

それに対して、ペアとなった 2 項目にSPSS により相関関係の分析を行った結果、互いに 有意差 (正の相関) が認められたのは「1/28 (-1)」(p<. 01)、「2/29 (-2)」(p<. 01)、「3/30 (-3)」 $(\mathrm{p}<.01) 、\lceil 4 / 31(-4)\lrcorner(\mathrm{p}<.01) 、\lceil 5 / 32(-5) 」(\mathrm{p}<.05) 、 「 27 / 54(-27)\lrcorner(\mathrm{p}<.01)$ である。 つまり、それらの理由については、取り除くことで学生が続けて日本語を履修する可能性 が大きいと言える。

ペアとなった 2 項目に相関関係が認められた、「学生が日本語を継続して学習しない理由 (6 項目)」と、「それらの理由がなくなれば継続して学習する意思（6 項目）」における それぞれの叙述統計の詳細は表 4 のようになっている。 
日本語の学習を継続しない理由についての一考察

一台湾の非日本語学科の大学生の場合一

表 4 なくなれば学生が続けて日本語を履修する可能性が大きい理由

\begin{tabular}{|c|c|c|c|c|c|c|c|}
\hline \multicolumn{4}{|c|}{$\begin{array}{c}\text { 日本語を続けて履修しない理由 } \\
(\mathrm{A})\end{array}$} & \multicolumn{4}{|c|}{$\begin{array}{c}\text { 左記の理由がない場合続けて日本語を履修する } \\
\text { (B) }\end{array}$} \\
\hline 項目 & 平均值 & 標準差 & 順位 & 項目 & 平均值 & 標準差 & 順位 \\
\hline 1 卒業したから。 & 1.78 & 1. 119 & 6 & $\begin{array}{l}28(-1) \text { 卒業して } \\
\text { いなかったら日本 } \\
\text { 語を続けて履修す } \\
\text { る。 }\end{array}$ & 3.59 & 1. 002 & 5 \\
\hline $\begin{array}{l}2 \text { 別の授業と時間が } \\
\text { 重なっているから。 }\end{array}$ & 3. 49 & 1. 414 & 1 & $\begin{array}{l}29(-2) \text { 別の授業 } \\
\text { と時間が重なって } \\
\text { いなかったら、日 } \\
\text { 本語を続けて履修 } \\
\text { する。 }\end{array}$ & 3. 72 & 1. 082 & 2 \\
\hline $\begin{array}{l}3 \text { 時間帯がよくない } \\
\text { (早寸ぎる、遅すぎ } \\
\text { る、または別の授業 } \\
\text { の時間とうまく組み } \\
\text { 合わせにくい) から。 }\end{array}$ & 2.69 & 1. 108 & 3 & $\begin{array}{l}30 \text { (-3) 時間帯が } \\
\text { 適当であれば（早 } \\
\text { すぎたり、遅すぎ } \\
\text { たりしない、また } \\
\text { は別の授業の時間 } \\
\text { とうまく組み合わ } \\
\text { せられるような } \\
\text { ら）日本語を続け } \\
\text { て履修する。 }\end{array}$ & 3.60 & 1. 109 & 4 \\
\hline $\begin{array}{l}4 \text { 他の勉学が忙しす } \\
\text { ぎるから。 }\end{array}$ & 3.45 & 1.240 & 2 & $\begin{array}{l}\text { 31(-4) 他の勉学 } \\
\text { が忙しくなかった } \\
\text { ら、日本語を続け } \\
\text { て履修する。 }\end{array}$ & 4. 01 & .977 & 1 \\
\hline $\begin{array}{l}5 \text { アルバイトなど他 } \\
\text { の用事が多すぎるか } \\
\text { ら。 }\end{array}$ & 2.55 & 1.231 & 4 & $\begin{array}{l}32(-5) \text { アルバイ } \\
\text { トなど他の用事が } \\
\text { 多くなかったら、 } \\
\text { 日本語を続けて履 } \\
\text { 修する。 }\end{array}$ & 3.64 & 1. 041 & 3 \\
\hline $\begin{array}{l}27 \text { より上級の日本語 } \\
\text { のクラスが開講され } \\
\text { ていないから。 }\end{array}$ & 2.13 & 1. 091 & 5 & $\begin{array}{l}54(-27) \text { より上級 } \\
\text { の日本語のクラス } \\
\text { が開講されたら、 } \\
\text { 日本語を続けて履 } \\
\text { 修する。 }\end{array}$ & 3.58 & .993 & 6 \\
\hline
\end{tabular}


この 12 項目において、組、または 2 組以上の標本について平均值に対する有意差がある かどうかに関して、それぞれ $\mathrm{t}$ 検定または分散分析（one way anova）を行った。まず、項 目 1 と項目 32 に男女差が検出され（表 5 ）、項目 1 は男性の方が有意的に高かった （2.00>1.42）が、項目 32 は女性の方が高かった（3.94>3.44）。また、学生の所属した学 部を理系と文系に分けて $\mathrm{t}$ 検定を行ったところ、顕著な差は認められなかった。しかし学 部をさらに表 1 に示寸 6 グループに分けて、分散分析を行ったところ、項目 1 にグループ 間の有意差が検出された（表 6 ）。ただし、どの学部とどの学部との間に差があるかは検 出されなかった（表 7 ）。

表 5 性別における $\mathrm{t}$ 検定

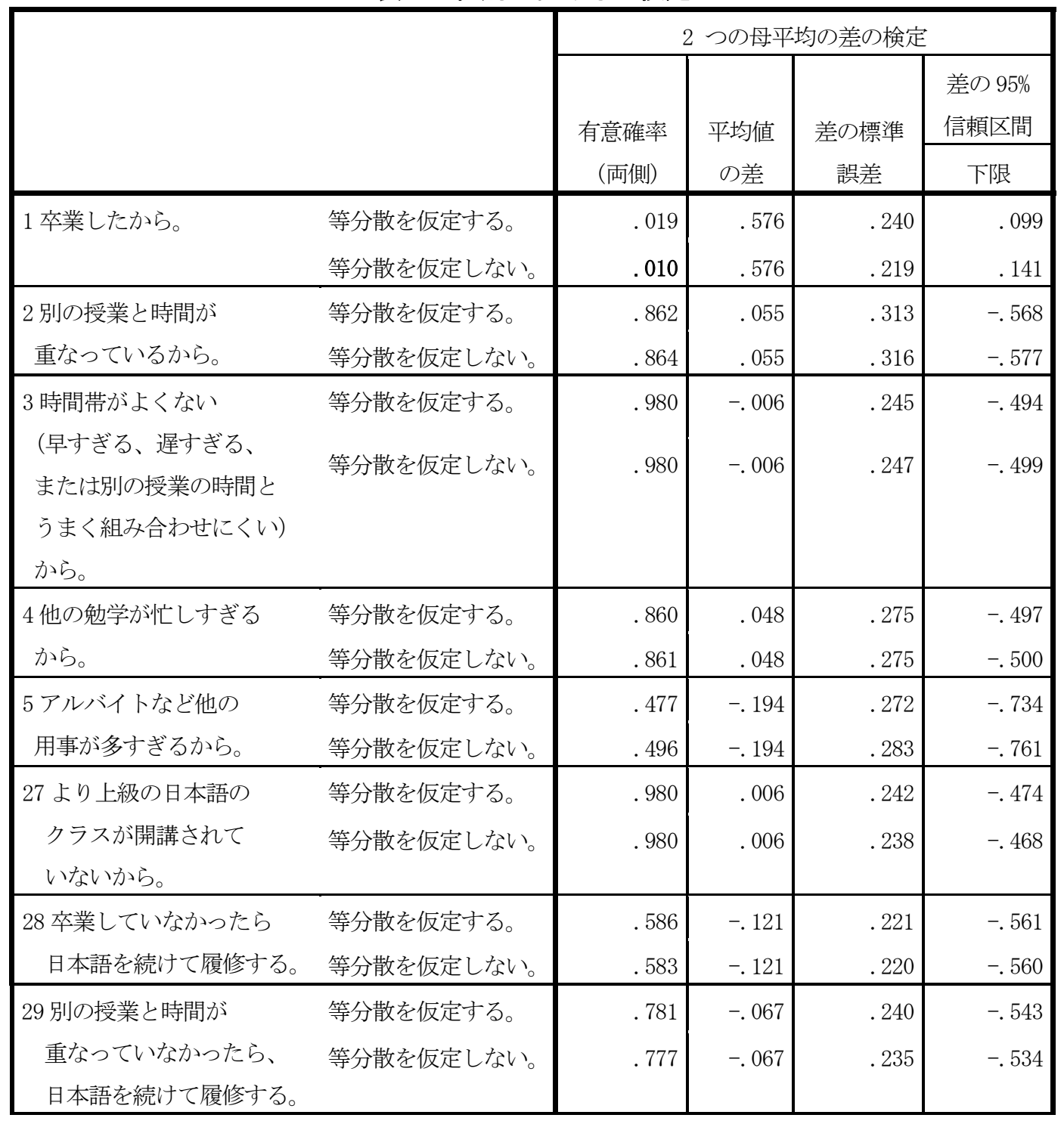


日本語の学習を継続しない理由についての一考察

一台湾の非日本語学科の大学生の場合一

\begin{tabular}{|c|c|c|c|c|c|}
\hline $\begin{array}{c}30 \text { 時間帯が適当であれば } \\
\text { (早すぎたり、遅すぎたり } \\
\text { しない、または別の授業の } \\
\text { 時間とうまく組み合わせ } \\
\text { られるようなら）日本語を } \\
\text { 続けて履修する。 }\end{array}$ & $\begin{array}{l}\text { 等分散を仮定する。 } \\
\text { 等分散を仮定しない。 }\end{array}$ & $\begin{array}{r}.159 \\
.159\end{array}$ & $\begin{array}{l}-.345 \\
-.345\end{array}$ & $\begin{array}{l}.243 \\
.243\end{array}$ & $\begin{array}{l}-.828 \\
-.830\end{array}$ \\
\hline $\begin{array}{l}31 \text { 他の勉学が忙しく } \\
\text { なかったら、日本語を } \\
\text { 続けて履修する。 }\end{array}$ & $\begin{array}{l}\text { 等分散を仮定する。 } \\
\text { 等分散を仮定しない。 }\end{array}$ & $\begin{array}{r}.557 \\
.547\end{array}$ & $\begin{array}{l}-.127 \\
-.127\end{array}$ & $\begin{array}{r}216 \\
.210\end{array}$ & $\begin{array}{l}-.556 \\
-.546\end{array}$ \\
\hline $\begin{array}{l}32 \text { アルバイトなど他の } \\
\text { 用事が多くなかったら、 } \\
\text { 日本語を続けて履修する。 }\end{array}$ & $\begin{array}{l}\text { 等分散を仮定する。 } \\
\text { 等分散を仮定しない。 }\end{array}$ & $\begin{array}{r}.019 \\
.013\end{array}$ & $\begin{array}{l}-.533 \\
-.533\end{array}$ & $\begin{array}{r}.223 \\
.209\end{array}$ & $\begin{array}{r}-.977 \\
-.950\end{array}$ \\
\hline $\begin{array}{l}54 \text { アルバイトなど他の } \\
\text { 用事が多くなかったら、 } \\
\text { 日本語を続けて履修する。 }\end{array}$ & $\begin{array}{l}\text { 等分散を仮定する。 } \\
\text { 等分散を仮定しない。 }\end{array}$ & $\begin{array}{r}.996 \\
.996\end{array}$ & $\begin{array}{r}.001 \\
.001\end{array}$ & $\begin{array}{l}.222 \\
.222\end{array}$ & $\begin{array}{l}-.441 \\
-.443\end{array}$ \\
\hline
\end{tabular}

表 6 学部における分散分析

1 卒業したから。

\begin{tabular}{|l|r|r|r|r|r|}
\hline & \multicolumn{1}{|c|}{ 平方和 } & \multicolumn{1}{c|}{ 自由度 } & \multicolumn{1}{c|}{ 平均平方 } & $\mathrm{F}$ 值 & 有意確率 \\
\hline グループ間 & 17.606 & 5 & 3.521 & 3.163 & .012 \\
\hline グループ内 & 91.292 & 82 & 1.113 & & \\
\hline 合計 & 108.898 & 87 & & & \\
\hline
\end{tabular}

表 7 多重比較

従属変数：1卒業したから。

Scheffe 法

\begin{tabular}{|c|c|c|c|c|c|c|}
\hline \multirow[b]{2}{*}{ (I) 学部 } & \multirow[b]{2}{*}{ (J) 学部 } & \multirow{2}{*}{$\begin{array}{c}\text { 平均值の差 } \\
(\mathrm{I}-\mathrm{J})\end{array}$} & \multirow[b]{2}{*}{ 標準誤差 } & \multirow[b]{2}{*}{ 有意確率 } & \multicolumn{2}{|c|}{ 平均値の $95 \%$ 信頼区間 } \\
\hline & & & & & 下限 & 下限 \\
\hline \multirow[t]{5}{*}{1 医 } & 2 電気 & -.484 & .340 & .844 & -1.64 & .67 \\
\hline & 3 工 & -1.022 & 349 & .139 & -2.21 & .17 \\
\hline & 4 管理 & .072 & 313 & 1.000 & -.99 & 1.14 \\
\hline & 5 デザイン & -.859 & .418 & .523 & -2.29 & .57 \\
\hline & 6 人文 & .516 & .561 & .973 & -1.40 & 2.43 \\
\hline
\end{tabular}




\begin{tabular}{|c|c|c|c|c|c|c|}
\hline \multirow[t]{5}{*}{2 電気 } & 1 医 & .484 & .340 & .844 & -.67 & 1.64 \\
\hline & 3 工 & -.538 & .406 & .880 & -1.92 & .85 \\
\hline & 4 管理 & .556 & .376 & .822 & -.73 & 1. 84 \\
\hline & 5 デザイン & -.375 & .468 & . 985 & -1.97 & 1.22 \\
\hline & 6 人文 & 1.000 & .598 & .731 & -1.04 & 3. 04 \\
\hline \multirow[t]{5}{*}{3 工 } & 1 医 & 1.022 & .349 & .139 & -.17 & 2.21 \\
\hline & 2 電気 & .538 & .406 & .880 & -.85 & 1.92 \\
\hline & 4 管理 & 1.094 & .384 & .163 & -.22 & 2. 40 \\
\hline & 5 デザイン & .163 & .474 & 1.000 & -1.45 & 1.78 \\
\hline & 6 人文 & 1.538 & .603 & .272 & -.52 & 3.60 \\
\hline \multirow[t]{5}{*}{4 管理 } & 1 医 & -.072 & .313 & 1. 000 & -1.14 & .99 \\
\hline & 2 電気 & -.556 & .376 & .822 & -1.84 & .73 \\
\hline & 3 工 & -1.094 & .384 & .163 & -2.40 & .22 \\
\hline & 5 デザイン & -.931 & .448 & .511 & -2.46 & .60 \\
\hline & 6 人文 & .444 & .583 & .988 & -1.54 & 2.43 \\
\hline \multirow[t]{5}{*}{5 デザイン } & 1 医 & .859 & .418 & .523 & -.57 & 2.29 \\
\hline & 2 電気 & .375 & .468 & .985 & -1.22 & 1.97 \\
\hline & 3 工 & -.163 & .474 & 1.000 & -1.78 & 1.45 \\
\hline & 4管理 & .931 & .448 & .511 & -.60 & 2.46 \\
\hline & 6 人文 & 1.375 & .646 & .482 & -.83 & 3.58 \\
\hline \multirow[t]{5}{*}{6 人文 } & 1 医 & -.516 & .561 & .973 & -2.43 & 1.40 \\
\hline & 2 電気 & -1.000 & .598 & .731 & -3.04 & 1.04 \\
\hline & 3 工 & -1.538 & .603 & .272 & -3.60 & .52 \\
\hline & 4 管理 & -.444 & .583 & .988 & -2.43 & 1.54 \\
\hline & 5 デザイン & -1.375 & .646 & .482 & -3.58 & .83 \\
\hline
\end{tabular}

\section{5. 継続学習への支援}

本研究の調查結果によると、「学生が卒業する前に」、「他の勉学やアルバイドが忙し すぎない前提で」、「別の授業と時間が重ならないよう」、「よい時間帯に」、「より上級の 日本語のクラスを開講すること」を配慮すれば、学生が続けて日本語を履修するように なる可能性が大きい。

逆に、学生が日本語の学習を継続しない理由としてあげた「望んだ日本語のレベルに 達した（アニメを見て分かるようになったり、日本旅行に十分だったりした）こと」、 「日本語の勉強を始めてから、日本語が難しいと気が付いたこと」、「日本語の文法や 論文 


\section{日本語の学習を継続しない理由についての一考察}

一台湾の非日本語学科の大学生の場合一

敬語がややこしいと思うこと」、「日本社会はルールや制限が多くて面倒くさいことを知り、 たとえ日本語が分かっても仮面をかぶってまで日本人と付き合いたくないと思ったこと」、 「将来日本語をあまり使うことはないと思うこと」、「もう日本語が上手であること」、 「日本語を習う目標（日本語能力試験に合格することなど）がなくなったこと」、「大学 で日本語を勉強するよりマイペースで勉強した方がいいと思うこと」、「自分の性格が 日本語の勉強に向いていないと思うこと」、「自分は日本語を勉強する能力がないと思う こと」、「日本語に興味を失ったこと」、「（学校や学科の規定などで）日本語を勉強 する必要がなくなったこと」、「（試験や宿題など）日本語の勉強の負担が大きいこと」、

「教師の教え方が自分と合わないこと」、「日本語の授業の進度が速すぎること」、「日本語 の成績があまりよくなかったこと」、「元々持っていた日本に対するいい印象がすっかり 消えたこと」、「日本語が上手でも重要視されないと思うこと」、「日本語の響きがあまり 好きになれないこと」、「日本語より先に英語を上達させる方が大事だと思うこと」、「他の 外国語を勉強した方がいいと思うこと」、を取り除いても学生の日本語学習継続にはあまり 有効でないかもしれない。

このように、取り除くことで効果が期待できるのは主に制度的な理由で、取り除いても 継続しない理由と性質上の違いがあることが見て取れる。

\section{6. おわりに}

本研究は、先行研究を参考にした他、日本語を 1 学期しか履修していない大学生 8 人に インタビューして得た情報に基づき、学生が日本語を続けて履修しない理由を 27 に絞って、 アンケート調査を行った。一方、この 27 の理由がなくなれば学生が日本語の学習を継続 するかについても探るため、それらの理由がなくなった場合に継続して日本語を学習する 意思についての 27 項目もアンケートに入れた。

調査結果はまず、「学生が日本語を継続して学習しない理由」における各項目の平均值は 「それらの理由がなくなった場合に継続して学習する意思」における各項目の平均值より 低い、ということが分かった。このような調査結果に至ったのは、学生が真面目に答え なかったこと、アンケートが不備であること、などの理由が考えられるが、アンケートで の質問の仕方も大きく関与していると考えられる。たとえ同じことについて質問したい 場合でも、本研究における項目 1〜27 のような「あなたが〜をしない理由は何か」という 真正面からの聞き方だと、低い数值を得たが、項目 28～54 のような「〜の状況であれば、 〜をするか」のように仮定の形で聞いたら高い数值を得ている。つまり、単刀直入に 聞かれたら、「正にその通りだ」と返事しにくいのに対して、「もうしそうであれば」という 条件の元で比較的積極的に「そうする」と答える傾向にある。質問の仕方により調査結果が 異なってくるわけである。 
また、この「学生が日本語を継続して学習しない理由（27 項目）」と「それらの理由が なくなった場合に継続して学習する意思 (27 項目)」との間には、相関関係が認められ なかった。つまり、学生は「Aという理由で〜をしないのである」と回答しているが、それは 必ずしも「Aという理由がなければ〜をする」ことにつながるとは限らない。これは、 いくつかの先行研究のように「学生が日本語を継続して学習しない理由」だけを究明しても、 「学生が日本語を継続して学習する」ための効果的な方策は得られないことを物語っている。

しかし、学生が日本語を継続して学習しない 27 の理由の中の 6 つの理由は「それらの 理由がなくなった場合に学生が継続して学習する意思」との間に、正の相関関係が検出 された。この、「学生が卒業したかどうか、「別の授業と時間が重なっているかどうか」、 「よい時間帯かどうか」、「他の勉学が忙しすぎるかどうか、「アルバイトなど他の用事が 多寸ぎるかどうか」、「り上級の日本語のクラスが開講されているかどうか」という6つ こそが、学生が続けて日本語を履修するかどうかを左右する真の理由ではなかろうか。

謝辞 : 本研究は台湾科技部が助成している研究計画（MOST106-2410-H-011-016-）の成果の一部である。 資料の整理に関して国防医学院の周雨青氏及び台湾科技大学の謝淑方氏に協力していただいた。 記して感謝の意を表したい。

\section{参考文献}

日本語

周萍（2009）「地域の日本語教室をやめた中国人学習者のケース・スタディ」『阪大日本語研究』21,129-150 岩本尚希（2010）「外国語学習者の学習継続要因に関する一考察一言語学習ヒストリーから一」『桜美林

言語教育論叢』 $6,29-43$

近藤裕美子・村中雅子（2010）「日本のポップカルチャー・ファンは潜在的日本語学習者といえるか」

『国際交流基金日本語教育紀要』6,7-21

吳展宇 (2011) 『日本語を第二外国語とする学習者の学習動機に関する一考察—グラウンデッド・セオリー の試み一』銘傳大学応用日本語学科修士論文

葉子婿（2013）『台湾における非専攻日本語学習者の学習動機および学習持続困難の要因』銘傳大学応用

日本語学科修士論文

洪良倩（2016）『台湾の大学における JFL 非専攻者の日本語の学習動機付け研究一継続学習を目指した

日本語教育一』東吳大学日本語学科博士論文

国際交流基金（2016）『2015 年度海外日本語教育機関調査結果（速報值）2016/11/10』 中国語

王敏東・謝淑方（2017）「臺灣日語學習人口及韓語學習人口的消長」『應用外語學報』27, $7-23$ 
付録

こんにちは。

\section{日本語の学習を継続しない理由についての調査}

このたびはアンケートへのご協力ありがとうございます。

この調査は日本語の学習支援についておたずねするものです。あなたのご返事はたいんん 重要な資料となります。実際の状況をお答えください。

調查結果は教育または研究にのみ使い、あなたの個人情報は公開いたしませんので、 じうか安心してご記入ください。

台湾科技大学応用外国語学科 教授 王敏東 2017 年 8 月

\section{I . まずあなたご自身のことについてうかがいます。}

1. お名前(苗字またはお名前のローマ字の頭文字だけでも結構です)：

2. 性別 : $\square$ 男 $\square$ 女 $\square$ その他(

3. 学部 : $\square$ 医学部 $\square$ 電気工学部 $\square$ 工学部 $\square$ 商学部 $\square$ デザイン学部 $\square$ 人文社会学部 $\square$ その他

4. 大学で開講されている日本語の授業をどのくらい履修していますか : $\square 1$ 学期のみ $\square 1$ 学期以上履修

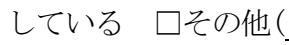

\section{II. 以下の各質問に最も当てはまるところに「V」を記入してください。}

\begin{tabular}{|c|c|c|c|c|c|c|}
\hline \multicolumn{7}{|c|}{ 一、日本語を続けて履修しない理由は？ } \\
\hline \multirow{2}{*}{\multicolumn{2}{|c|}{ 項目 }} & 非常に & 当ては & 普 & 当ては & 全然当 \\
\hline & & 当ては & まる & 通 & まらな & てはま \\
\hline 1 & 卒業したから。 & & & & & \\
\hline 2 & 別の授業と時間が重なっているから。 & & & & & \\
\hline 3 & $\begin{array}{l}\text { 時間帯がよくない（早すぎる、遅すぎる、 } \\
\text { または別の授業の時間とうまく組み合わせ } \\
\text { にくい）から。 }\end{array}$ & & & & & \\
\hline 4 & 他の勉学が忙しすぎるから。 & & & & & \\
\hline 5 & アルバイトなど他の用事が多すぎるから。 & & & & & \\
\hline 6 & $\begin{array}{l}\text { 望んだ日本語のレベルに達した（アニメを } \\
\text { 見て分かるようになったり、日本旅行に十分 } \\
\text { だったりした）から。 }\end{array}$ & & & & & \\
\hline
\end{tabular}




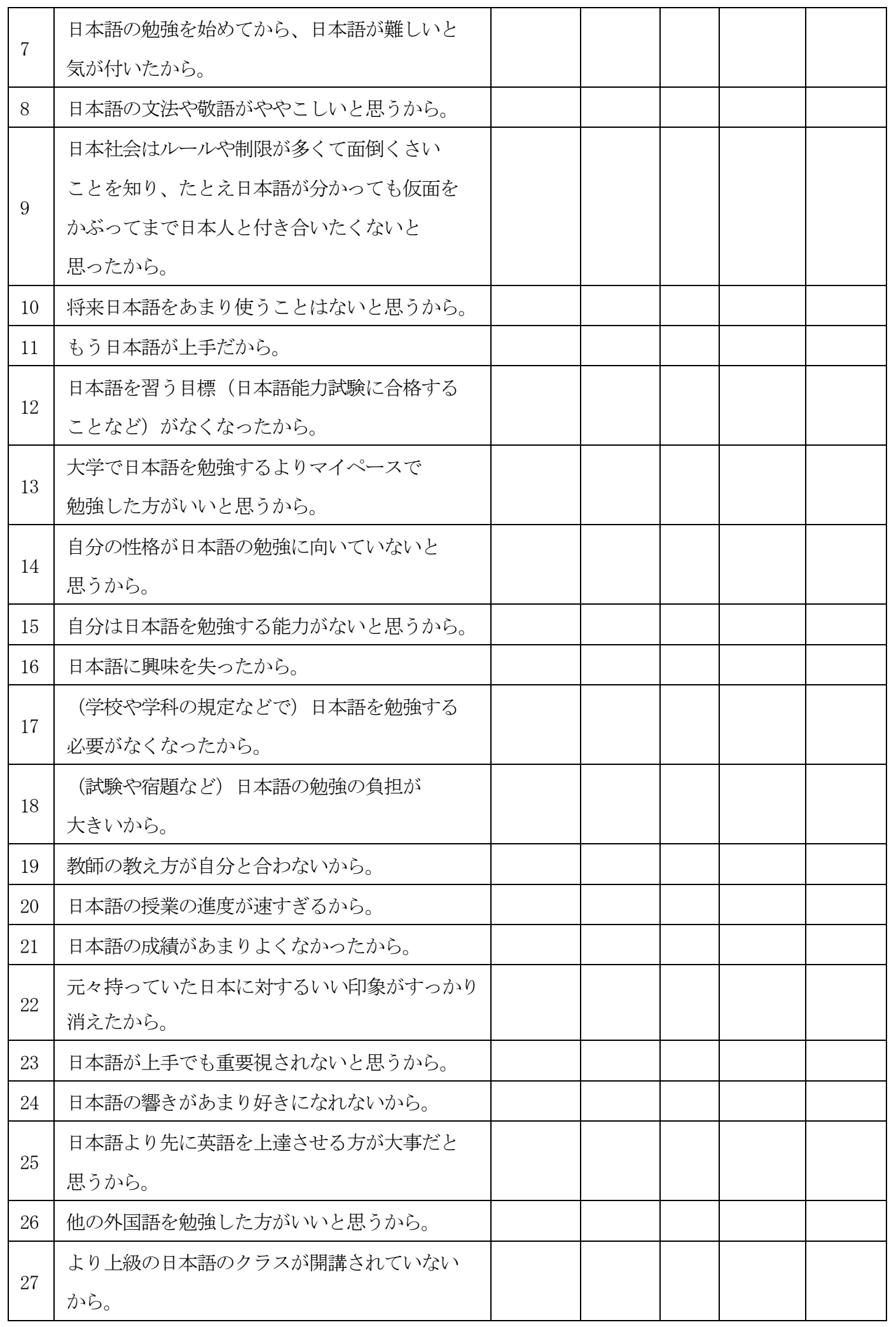




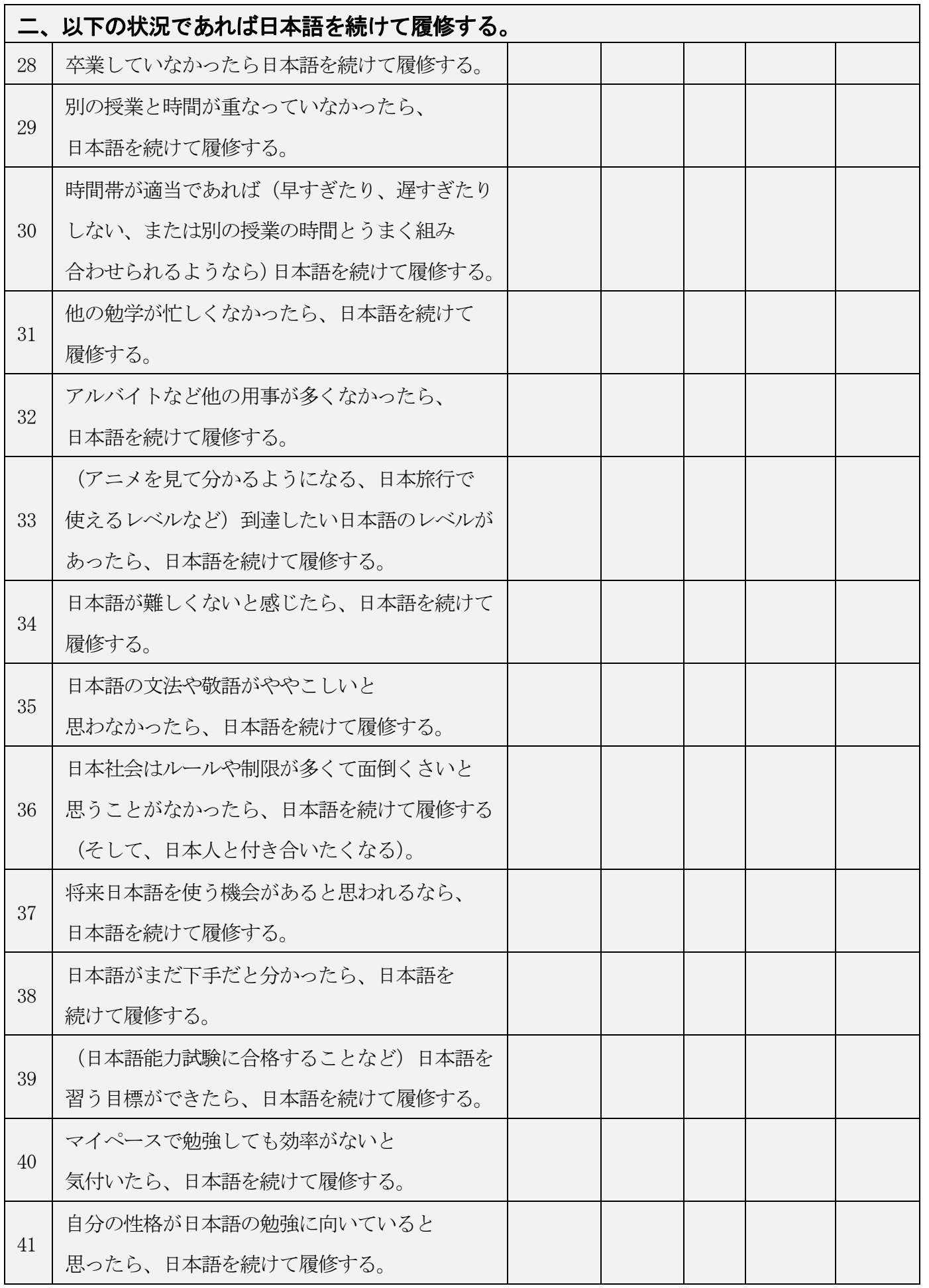




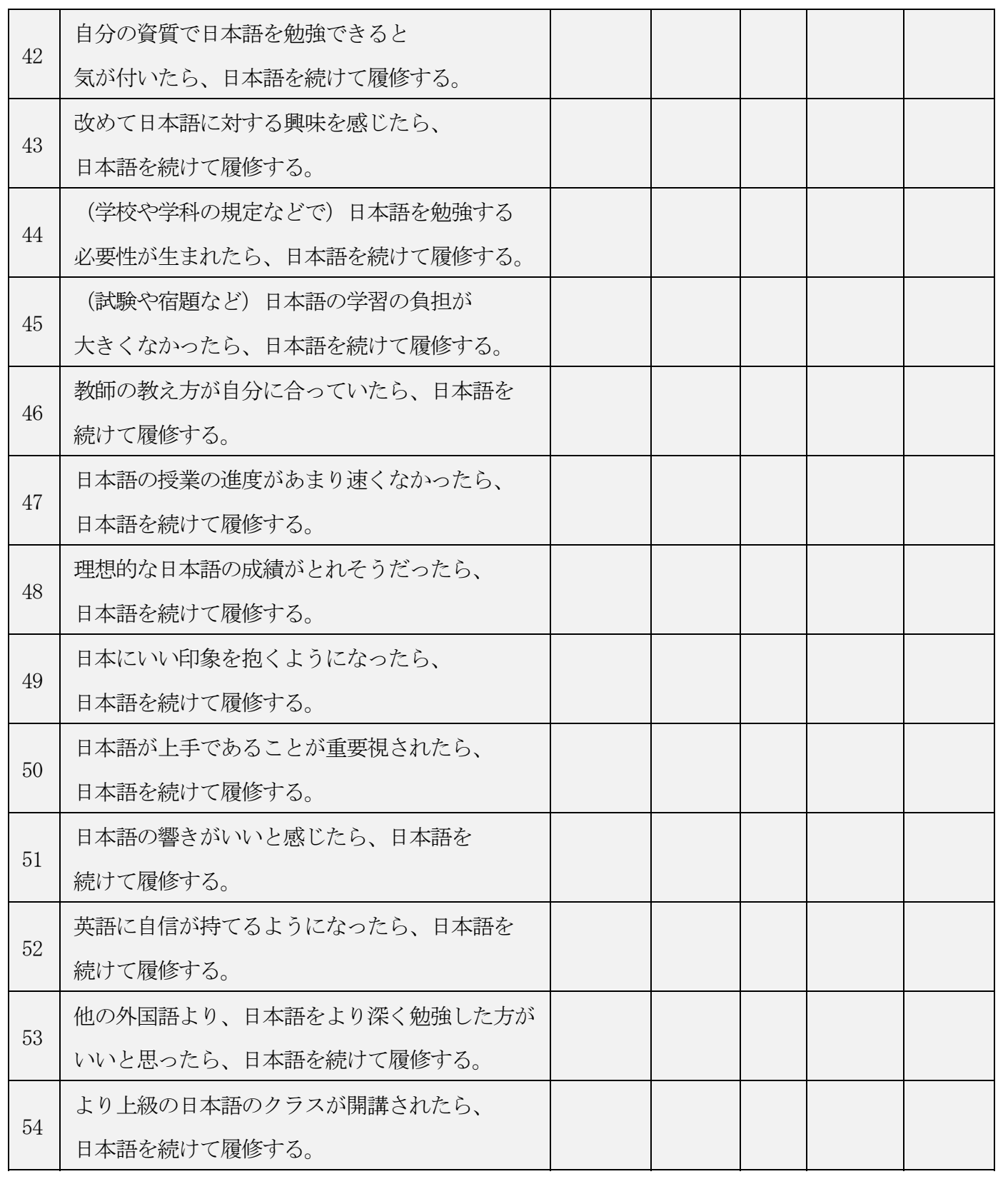

将来機会があれば日本語の学習に関するインタビューを受けてもいいと思いますか。 ロいいえ $\square$ は(連絡方法 :

$$
\text { アンケートはこれで終ります。ご協力ありがとうございました。 }
$$

